\begin{tabular}{|ll|}
\hline Received & $:$ 30 September 2019 \\
Revised & $:$ 1 Oktober 2019 \\
Accepted & $:$ 22 Oktober 2019 \\
Online & $:$ 25 Oktober 2019 \\
Published & $:$ 29 Oktober 2019 \\
\hline
\end{tabular}

\title{
KARAKTERISASI BIOPLASTIK DARI RUMPUT LAUT (EUCHEUMA COTTONII) DAN PATI SINGKONG DENGAN PENAMBAHAN PATI BIJI ALPUKAT
}

\author{
Gracia Ramadhani Putri \\ Fakultas Matematika dan Ilmu Pengetahuan Alam, Universitas Negeri Jakarta \\ email: graciaramadhani17@gmail.com
}

\begin{abstract}
The increasing use of plastics in everyday life results in environmental pollution. Synthetic plastic is difficult to be degraded in nature, so we need the main material for making environmentally friendly plastics. This research was conducted to synthesize seaweed-based biodegradable plastic (Eucheuma cottonii) mixed with cassava starch and polysaccharides derived from various tropical fruit seeds that are widely available in Indonesia such as avocado and durian with a composition ratio of 3:8:1. Characterization carried out included functional group analysis with FTIR, mechanical properties (tensile strength) and biodegradability.
\end{abstract}

Key words : Biodegradable, Bioplastic, Ft-Ir, Starch, Seaweed, Tensile Strength.

\begin{abstract}
Abstrak
Meningkatnya penggunaan plastik dalam kehidupan sehari-hari menghasilkan pencemaran lingkungan. Plastik sintetis sulit terdegradasi di alam, jadi kita membutuhkan bahan utama untuk membuat plastik ramah lingkungan. Penelitian ini dilakukan untuk mensintesis plastik biodegradable berbasis rumput laut (Eucheuma cottonii) dicampur dengan pati singkong dan polisakarida yang berasal dari berbagai biji buah tropis yang banyak tersedia di Indonesia seperti alpukat dan durian dengan perbandingan komposisi 3: 8: 1. Karakterisasi yang dilakukan meliputi analisis kelompok fungsional dengan FTIR, sifat mekanik (kekuatan tarik) dan biodegradabilitas.
\end{abstract}

Kata kunci: Biodegradable, Bioplastik, Ft-Ir, Pati, Rumput Laut, Kekuatan Tarik.

\section{PENDAHULUAN}

Plastik adalah polimer sintetis yang tersusun atas monomer-monomer yang saling terikat atau berhubungan satu dengan yang lainnya. Plastik bersifat kuat, ringan, dan praktis sehingga dapat digunakan sebagai bahan pengemas baik makanan ataupun lainnya. Kebutuhan akan plastik sangat besar sehingga memicu permasalahan lingkungan di dunia terutama di Indonesia berupa sampah plastik. Di Indonesia, menurut data statistik persampahan domestik Indonesia, jenis sampah plastik menduduki peringkat kedua sebesar 5,4 juta ton per tahun atau 14\% dari total produksi sampah.

Salah satu bahan yang dapat digunakan dalam pembuatan bioplastik adalah pati. Pati merupakan polisakarida yang serbaguna dan melimpah di bumi. Pati dapat diubah menggunakan teknologi yang ada, jumlahnya melimpah dan murah (A. Ali, 2008). Pada penelitian ini digunakan sumber pati yang 
berasal dari biji alpukat dan pati singkong sebagai bahan dasar bioplastik. Menurut Winarti (2006) biji alpukat mengandung pati sebesar 80,1\% dengan kadar amilosa 43,3\% dan amilopektin 36,8\%.

Hasil penelitian yang telah dilakukan oleh Muhammad Afif (2018) yang berjudul "Pembuatan dan Karakterisasi Bioplastik dari Pati Biji Alpukat-Kitosan dengan Plasticizer Sorbitol" menunjukkan bioplastik dengan karakteristik sifat mekanik pada variasi rasio massa pati biji alpukat : kitosan didapatkan pada formula 3:2 dengan nilai kuat tarik $6,40 \mathrm{MPa}$, elongasi $6,87 \%$, elastisitas $0,93 \mathrm{MPa}$ dengan daya serap air $120,86 \%$ pada suhu $26^{\circ} \mathrm{C}$ dan $127,32 \%$ pada suhu $50^{\circ} \mathrm{C}$. Hasil bioplastik dengan karakteristik sifat mekanik terbaik pada variasi sorbitol didapatkan pada penambahan sorbitol $3 \mathrm{~mL}$ dengan nilai kuat tarik 2,28 MPa, elongasi $17,58 \%$, elastisitas $0,13 \mathrm{MPa}$, dengan daya serap air $88,23 \%$ pada suhu $26^{\circ} \mathrm{C}$ dan $87,39 \%$ pada suhu $50^{\circ} \mathrm{C}$ serta persen degradasi sebesar $41,35 \%$.

Plastik merupakan material yang banyak digunakan dalam kehidupan manusia terutama untuk kemasan, mempunyai sifat ringan, mudah digunakan dan harganya terjangkau serta digunakan lebih dari 30 juta ton sebagai bahan kemasan (Nurul Asni, 2015). Plastik yang digunakan saat ini merupakan plastik polimer sintetik yang terbuat dari minyak bumi (non-renewable) yang tidak dapat terdegradasi oleh mikroorganisme di lingkungan (Said, 2018). Sebagian besar plastik yang diproduksi dan dikonsumsi tersebut akan menjadi limbah industri di lingkungan karena termasuk jenis polimer yang memiliki ketahanan terhadap penguraian secara biologis akibat berat molekulnya yang sangat besar, jumlah cincin aromatik yang sangat tinggi, dan ikatan-ikatan yang kompleks (Atmaja, 2016).

Pati adalah bahan baku yang paling menarik untuk pengembangan dan produksi bioplastik. Pati tersimpan dalam berbagai tanaman dalam bentuk butiran mikroskopis. Pati benar-benar bersifat biodegradable dalam berbagai kondisi lingkungan. Pati dapat dihidrolisis menjadi glukosa oleh mikroorganisme atau enzim, dan kemudian dimetabolisme menjadi karbon dioksida dan air (Dyah, 2000).

Tanaman alpukat (Persea americana, Mill) merupakan tanaman yang berasal dari daratan tinggi Amerika Tengah dan memiliki banyak varietas yang tersebar di seluruh dunia. Menurut Winarti \& Purnomo (2006) biji alpukat mengandung pati sebesar 80,1\% dengan kadar amilosa 43,3\% dan amilopektin 36,8\% (Chandra, 2013).

Winarti (2006) dalam penelitiannya yang berjudul pengaruh $\mathrm{pH}$ dan jenis pelarut pada perolehan dan karakterisasi pati dari pati biji alpukat dengan memperoleh kadar pati terbaik sebesar 74,68\%. Kandungan pati dalam biji alpukat yang terbilang cukup tinggi menjadikan alpukat berpotensi menjadi bahan baku bioplastik.

Ampas rumput laut dapat digunakan sebagai bahan baku biodegradable film. Pada industri rumput laut bagian yang digunakan hanya sekitar 30 - 35\%, sedangkan $65-70 \%$ menjadi limbah yang belum banyak dimanfaatkan (Wekridhany, 2012).

Berdasarkan hal tersebut, salah satu solusi terbaik untuk mengatasi pencemaran lingkungan akibat sampah plastik adalah dengan membuat plastik biodegradable (bioplastik). Bioplastik merupakan plastik yang seluruh atau hampir seluruh komponennya berasal dari bahan baku yang dapat diperbaharui. Bioplastik mempunyai sifat ramah lingkungan karena sifatnya yang dapat kembali ke alam. Bioplastik dirancang untuk memudahkan proses degradasi terhadap reaksi enzimatis mikroorganisme pengurai seperti bakteri dan jamur.

\section{METODE PENELITIAN}

Metode penelitian ini adalah penelitian eksperimen (true experiment), diartikan sebagai metode yang digunakan untuk mencari pengaruh perlakuan tertentu terhadap yang lain dalam kondisi yang terkendalikan. Sampel pada penelitian ini adalah rumput laut yang dihaluskan dengan air, pati biji alpukat serta pati singkong. Masing-masing bahan yang telah dihaluskan kemudian diekstrak patinya dan dibuat bioplastik dengang perbandingan 3:8:1. Hasil bioplastik kemudian diuji karatkeristiknya menggunakan instrument FTIR, uji tensile strength, dan uji biodegradable dalam tanah selama 14 hari.

e-Journal : http:/ / ejurnal.kpmunj.org 


\section{HASIL DAN PEMBAHASAN}

Hasil sintesis bioplastik yang dilakukan dari rumput laut, pati singkong dan penambahan pati biji alpukat dengan perbandingan konsentrasi masing-masing yaitu 3:8:1 diperoleh produk sebagai berikut.

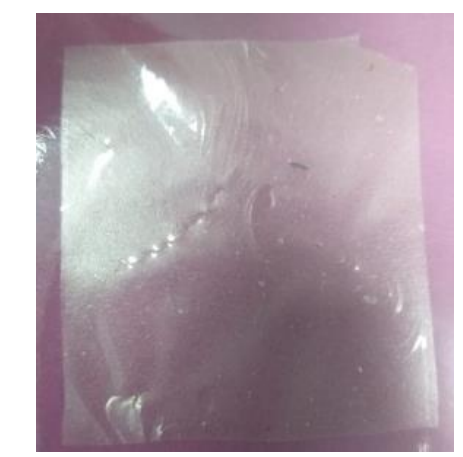

Gambar 1. Hasil Sintesis Bioplastik

Hasil sintesis bioplastik memiliki warna yang bening dengan sedikit kemerahan. Warna kemerahan ini disebabkan karena biji alpukat memiliki senyawa fenolik dopa (3,4-dihidroksi fenilalanin). Senyawa fenolik tersebut dapat menyebabkan adanya reaksi pencoklatan (browning) secara enzimatik yang disebabkan oleh reaksi antara oksigen dengan substrat fenolik dengan katalisator polifenol oksidase.

Polifenol oksidase adalah enzim yang mengandung tembaga $(\mathrm{Cu})$ yang mengkatalis oksidasi senyawa fenol. Aktivitas tersebut mengubah gugus monofenol menjadi O-hidroksi fenol (difenol), yang selanjutnya diubah lagi menjadi o-kuinon. O-kuinon mengalami polimerisasi non enzimatik menghasilkan melanin yang merupakan pigmen berwarna gelap (C. Queiroz 2008).

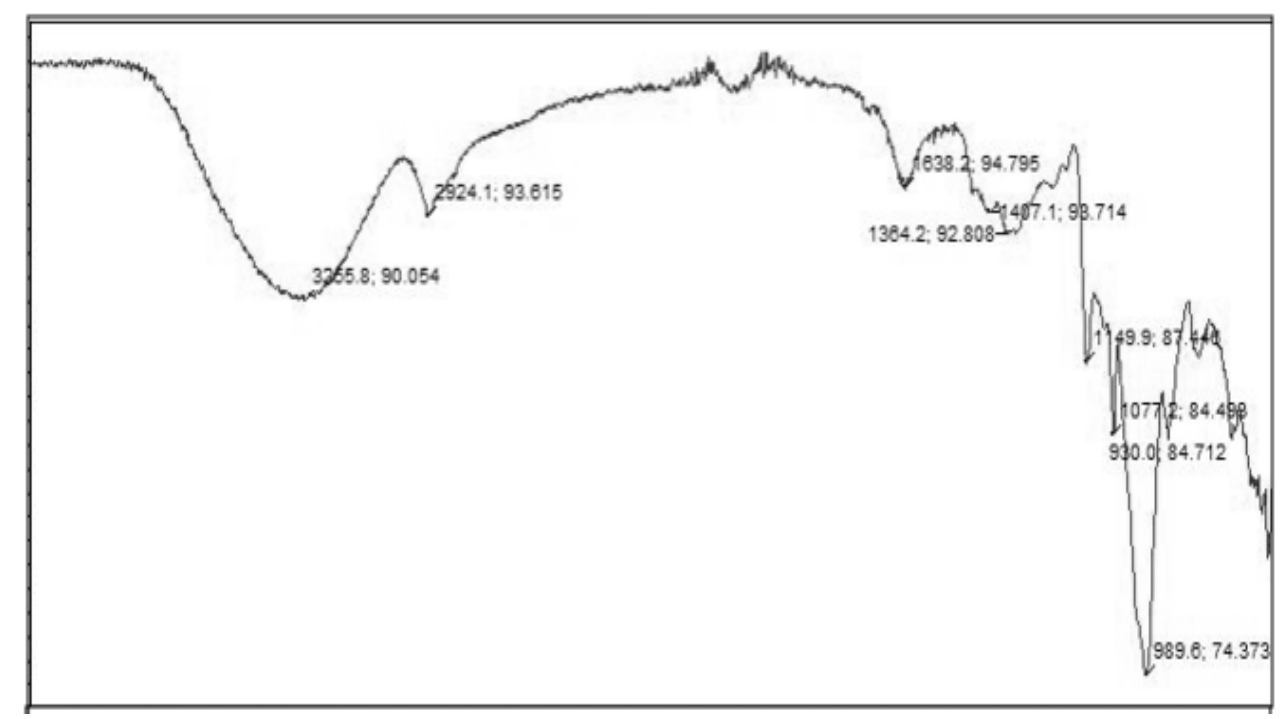

Gambar 2 Hasil Karakterisasi gugus fungsi pada bioplastik menggunakan FTIR 
Hasil sintesis bioplastik dari rumput laut, pati singkong, dan pati bji alpukat kemudian dikarakterisasi dengn FTIR. Tujuan dari uji FTIR untuk mengetahui gugus-gugus fungsi dari bioplastik biji alpukat.

Analisis pada bioplastik dari biji alpukat terdapat bilangan gelombang $3256 \mathrm{~cm}^{-1}$ yang menunjukkan adanya gugus $\mathrm{O}-\mathrm{H}$ alkohol. Bilangan gelombang $2924 \mathrm{~cm}^{-1}$ menunjukkan ikatan $\mathrm{C}-\mathrm{H}$ alkana. Kemudian bilangan gelombang $1638 \mathrm{~cm}^{-1}$ menunjukkan adanya gugus khas pati yaitu ikatan C-C. Selain itu pada rentang frekuensi 900-1250 cm-1 yaitu 930, 989, 1077 dan $1149 \mathrm{~cm}^{-1}$ menunjukkan adanya gugus C-O pada pati (Chandra, 2013).

Munculnya bilangan gelombang tersebut pada bioplastik mengindikasi telah terjadi interaksi berupa ikatan hidrogen amilum-amilopektin. Hasil FT-IR pada bioplastik ini menunjukkan tidak adanya kemunculan gugus fungsi yang baru, dengan kata lain secara kimia tidak terjadi perubahan, sehingga proses pembuatan bioplastik merupakan pencampuran secara fisik (A. Sofia, 2017).

Biodegradasi adalah penyederhanaan sebagian atau penghancuran seluruh bagian struktur molekul senyawa oleh reaksi-reaksi fisiologis yang dikatalisis oleh mikroorganisme (Madsen, 1997 dalam Ummah (2012)). Metode yang digunakan adalah metode soil burial test (Subowo dan Pujiastuti, 2003 dalam Ummah (2012)) yaitu dengan metode penanaman sampel dalam tanah. Sampel berupa film bioplastik ditanamkan pada tanah yang ditempatkan dalam pot dan diamati per-hari terdegradasi secara sempurna. Proses degradasi film plastik dalam tanah. Analisis biodegradasi film plastik dilakukan melalui pengamatan film secara visual.

Hasil dari uji degradarsi bioplastik biji alpukat yaitu biji alpukat mengalama tingkat degradasi sebanyak 53,54\%. Dari hasil degradasi tersebut, dapat dilihat bahwa hasil sintesis bioplastik telah terurai lebih dari setengahnya hanya dalam waktu 14 hari. Hal ini terjadi berkaitan dengan hidrolisis pati oleh mikroorganisme, dimana pati dapat dihidrolisis menjadi glukosa oleh mikroorganisme atau enzim, dan kemudian dimetabolisme menjadi karbon dioksida dan air (Dyah, 2000).

Selanjutnya, mikroorganisme akan menguraikan polimer-polimer dengan mengkatalisis hidrolisis dan oksidasi molekul karbohidrat yang dimiliki dalam biji alpukat. Mikroorganisme yang mengkonsumsi pati akan membentuk pori-pori dalam matrik polimer dan memberikan gugus-gugus yang rentan untuk terdegradasi (Park, 2002).

Kekuatan tarik merupakan tegangan maksimum yang dibutuhkan oleh spesimen untuk menahan gaya yang diberikan. Pengujian kekuatan tarik dari campuran rumput laut, variasi pati biji durian dan alpukat serta penambahan pati singkong merupakan faktor yang penting untuk menentukan kondisi optimum sifat mekanis bioplastik yang diinginkan.

Hasil sintesis bioplastik biji alpukat memiliki kekuatan tarik $1.01 \mathrm{mPA}$, memiliki besar pemanjangan $0.93 \%$ dan memiliki pemanjangan ketika terjadi break $0.5 \%$. Faktor yang memengaruhi kekuatan tensile strength pada bioplastik adlah adanya kandungan amilosa pada biji alpukat. Amilosa adalah polimer rantai lurus D-glukosa yang memainkan peran yang sangat penting dalam pembentukan lembaran film yang kuat. Semakin tinggi kandungan amilosa semakin tidak elastis lembaran film (D. R. Lu, C. M. Xiao, and S. J. Xu, 2009).

\section{KESIMPULAN}

Berdasarkan pada penelitian komposit film dari campuran rumput laut, pati singkong dan pati biji alpukat telah dikembangkan. Berdasarkan karakteristik gugus fungsi, mekanis dan kemampuan terurai, komposit film bioplastik yang dicampur dengan biji alpukat telah menunjukkan karakteristik yang menjanjikan untuk aplikasi bioplastik dalam industri pengemasan. Hal ini ditinjau hasil pengujian terhadap komposit film bioplastik pada penambahan pati biji tersebut, dimana komposit film bioplastik dari pati biji alpukat mempunyai kemampuan 53.54\%. terdegradasi dalam tanah selama 14 hari. Selain itu, kekuatan pemanjangan (tensile strength) pati biji alpukat yaitu sebesar 1,01 mPA serta hasil perpanjangan $0,93 \%$ dan perpanjangan putus $0,5 \%$. Spektra IR menunjukkan tidak adanya gugus fungsional baru. 


\section{REFERENSI}

A. Ali, M. S. Memon. 2008. Incorporation of Enteromorpha procera Ahlner as nutrition supplement in chick's feed. International Journal Biology and Biotechnology: 211-214.

A. Sofia, A.T. Prasetya, dan E. Kusumastuti. 2017. Komparasi Bioplastik Kulit Labu Kuning Kitosan dengan Plasticizer dari Berbagai Variasi Sumber Gliserol. Indonesian Journal of Chemical Science, 6(2): 110-116.

Afif ,Muhammad., Wijayati, Nanik., Mursiti, Sri. 2018. Pembuatan dan Karakterisasi Bioplastik dari Pati Biji Alpukat-Kitosan dengan Plasticizer Sorbitol. Indonesian Journal of Chemical Science.

Atmaja, M. W. 2016. Pembuatan dan Karakterisasi Film Pati Kulit Ari Singkong/Kitosan. Indonesia Journal of Chemical Science: 28-35.

C. Queiroz, M. L. M. Lopez, E. Fialho, V. L. V. Mesquita. 2008. Polyphenol Oxidase: Characteristics and Mechanisms of Browning Control. Food Review International: 361-375.

Chan, H. T. 1983. Handbook Of Tropical Foods. New York and Bassel: Marcel Dekker Inc.

Chandra, A. 2013. Pengaruh pH dan Jenis Pelarut pada Perolehan dan Karakterisasi Pati Biji Alpukat. Prosiding Seminar Nasional Teknik Kimia, Teknologi Oleo dan Petrokimia Indonesia. Riau.

Damayanti, Dessy. 2003. Teknologi Proses Pembuatan dan Karakterisasi Plastik dari Bahan Campuran Polipropilen dan Tapioka. Skripsi. Bogor : IPB

Dyah, O. Y. Primarini. 2000. Some Enzyme Properties of Raw Starch Digesting Amylases of Sterptomyces sp. Starch: 28-32.

D. R. Lu, C. M. Xiao, and S. J. Xu, 2009. Starch-based completely biodegradable polymer materials. Express Polym. Lett.,3(6): 366-375.

Julianto. 2014. Tabloid Sinar Tani. Diakses di http://tabloidsinartani.com/content/read/produksisingkong-nasional (accessed Mei 2019).

Lehninger, A. 1982. Dasar-Dasar Biokimia. Jakarta: Erlangga.

Martina, M. I. Sufiya Putri. 2016. Analisis Plastik Biodegradable Berbahan Dasar Nasi Aking. Jurnal Ilmu Pendidikan Fisika: 9-12.

Nurul Asni, Djonaedi Saleh, Nadia Rahawati. 2015. Plastik Biodegradable Berbahan Ampas Singkong dan Polivinil Asetat. Seminar Nasional Fisika. Jakarta: Universitas Negeri Jakarta. 57-62.

Park, H. 2002. Preparatio and Properties Biodegradable Thermoplasttic Starch/Clay Hybrids. Macromolecular Materials and Engineering: 553-558.

Rukmana, R. 1986 . Ubi Kayu, Budidaya, dan Pasca Panen. Yogyakarta: Penerbit Kanisius.

Said, A. 2018. Sintesis Plastik Biodegradable Berbahan Komposit Pati Sagu- Kitosan Sisik Ikan Katamba (Lethrinus lentjam.). Jurnal Inovasi Pendidikan Sains: 23-30.

Singh, J. N. Swamy dan B. 2010. Bioplastics and global sustainability. Plastics Research Online Society of Plastics Engineers 
Ummah, Natiqoh Al. 2012. Uji ketahanan Biodegradable Plastic Berbasis Tepung Biji Durian Terhadap Air dan Pengukuran Densitasnya. Skripsi, Semarang: Universitas Negeri Semarang.

Utami, Yuli, D \& Herti. 2010. Studi Pembuatan Dan Karakteristik Sifat Mekanik Dan Hidrofobilitas Bioplastik Dari Pati Sorgum. Jurnal Rekayasa Kimia Dan Lingkungan. 7(4): 190-195.

Wekridhany, A. 2012. Pengaruh Rasio Selulosa/ NaOH pada Tahap Alkalinisasi terhadap Peningkatan Produksi Natrium Karboksimetil selulosa ( Na-CMC) dari Residu Rumput Laut Eucheuma Spinossum. Jurnal Penelitian Jurusan Teknik Kimia.

Winarno, F. G. 1984 . Kimia Pangan dan Gizi. Jakarta: Gramedia.

Winarno, F. 1990. Singkong dan Pengolahannya. Jakarta: Penerbit Aksara Baru.

Winarti, S. 2006. Olahan Biji Buah. Surabaya: Trubus Agrisarana.

Yorita, N. 2010. Karakteristik Permen Jelly Rumput Laut Kappaphycus alvarezzi dengan Penambahan Pati Termodikfikasi Sebagai Bahan Pengisi. Skripsi. IPB.

Yamaguchi, V. E. Rubatzky dan M. 1995. Sayuran Dunia. Bandung: ITB.

Zulferiyenni. 2014. Pengaruh Konsentrasi Gliserol Dan Tapioka Terhadap Karakteristik Biodegradable Film Berbasis Ampas Rumput Laut Eucheuma cottonii. Jurnal Teknologi dan Industri Hasil Pertanian: 257-273. 